Bangladesh J. Plant Taxon. 23(2): 161-166, 2016 (December)

(C) 2016 Bangladesh Association of Plant Taxonomists

\title{
MORPHOLOGICAL AND ANATOMICAL STUDIES OF THE NEWLY RECORDED GENUS PLAGIOPTERON GRIFF. (CELASTRACEAE) FROM VIETNAM
}

\author{
VU Tien Chinh, Ritesh Kumar Choudhary ${ }^{1}$, Tran The Bach, \\ Bui hong Quang, DO VAn Hai, SANGmi Eum ${ }^{2}$ AND JoongKu LeE ${ }^{3 *}$ \\ Institute of Ecology and Biological Resources, \\ Vietnam Academy of Sciences and Technology, Hanoi, Vietnam
}

Keywords: Anatomy; Celastraceae; New generic record; Plagiopteron; Vietnam.

\begin{abstract}
Plagiopteron Griff. (Celastraceae), collected from Bac Giang Province of Vietnam is reported here as a new generic record for the flora of Vietnam. It is supposedly an early derived member of the subfamily Hippocrateoideae (composed of tribes Campylostemoneae and Hippocrateeae), within Hippocrateaceae. The genus differs from other members of Celastraceae by its many bicyclically arranged stamens. Leaf anatomical studies have been performed to understand various features such as venation, vascular bundles, collenchyma and stomata. Taxonomic notes, description, and photographs are provided, together with short notes on the distribution, ecology and phenology of the species.
\end{abstract}

\section{Introduction}

The family Celastraceae is represented by 98 genera and 1264 species and distributed across tropics and subtropics, some in temperate regions of the world (Simmons, 2001). In Vietnam, they are represented by 13 genera and 80 species (Ban, 2003). During a recent field work in An Lac Village of Bac Giang Province in Vietnam (Fig. 1), an interesting plant belonging to Celastraceae was collected. After examining all the specimens housed in Vietnamese herbaria (HN, HNU, VNM) the collected specimens did not match with any known Vietnamese genus. Critical morphological and anatomical observation, consultation of type specimens and relevant literature studies were carried out and conclusively it was identified as Plagiopteron suaveolens Griff. The genus differs from other members of the family Celastraceae by its many bicyclically arranged stamens. This monotypic genus was hitherto known to occur in South China, Myanmar, Bangladesh and Thailand. The present report is a new distributional record of this genus in Vietnam.

Leaf anatomical studies have been proved useful in the solution of certain taxonomic and phylogenetic problems and delimitation of various genera (Robinson, 1969; Cutler et al., 2007). The importance of anatomical characters for the Celastraceae taxonomy was confirmed by Smith \& Robinson (1971), Den Hartog et al. (1978) and Mennega (1997). Smith \& Robinson (1971) used leaf epidermal features in the definition of species Hippocrateaceae occurring in Santa Catarina. Den Hartog et al. (1978) supported the expansion of the Celastraceae family concept based on the types of stomata and crystal-cells in the leaf epidermis of Celastraceae s.l. Considering the importance of anatomical studies in Celastraceae, we carried out the same for Plagiopteron.

\footnotetext{
${ }^{1}$ Biodiversity \& Palaeobiology Group, Agharkar Research Institute, G.G. Agarkar Road, Pune, India.

${ }^{2}$ International Biological Material Research Center, Korea Research Institute of Bioscience and Biotechnology, Daejeon, Republic of Korea

${ }^{3}$ Department of Environment and Forest Resources, Chungnam National University, Daejeon, Republic of Korea

*Corresponding author.
} 


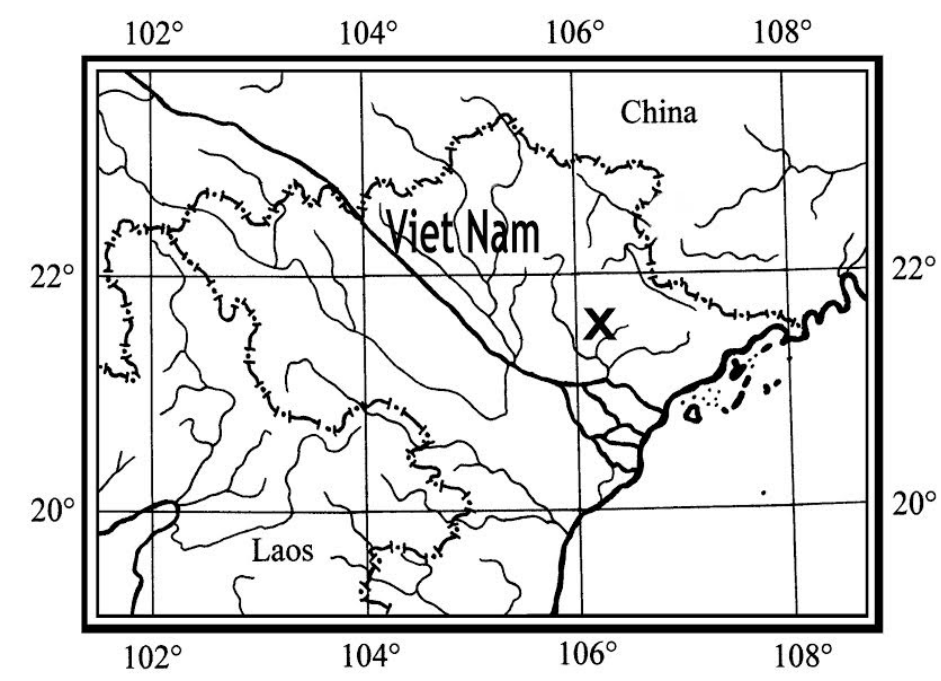

Fig. 1. Distribution map showing location of Plagiopteron suaveolens in Vietnam.

\section{Materials and Methods}

The specimens were collected from the natural habitats, thoroughly processed using standard herbarium techniques (Jain and Rao, 1977) and deposited in Herbarium of Institute of Ecology \& Biological Resources (HN) Vietnam and Korea Research Institute of Bioscience \& Biotechnology (KRIB). Inflorescences were fixed in FAA ( $5 \mathrm{ml}$ of Formalin: $5 \mathrm{ml}$ of Glacial Acetic acid: $90 \mathrm{ml}$ of Ethyl Alcohol) solution and detailed morphological studies were carried out under Nikon Eclipse Ci Stereo Microscope. Photographs were taken using Nikon DS-Fi2 Camera.

Leaves were fixed in FAA and then stored in $70 \%$ ethanol to minimize hardening. Samples were taken from the main vein and the region between the midrib and margin. Cross-sections were performed in a rotary microtome, colored in methylene blue and carmine red, and then assembled according to standard techniques of plant anatomy (Johansen, 1940). The anatomical analysis and photographic documentation pertaining to light microscopy were performed under light microscope Nikon Eclipse Ci with DS-Fi2 Camera.

\section{Results}

\section{Taxonomic Treatment}

Plagiopteron Griff. Calcutta J. Nat. Hist. 4: 244, 1844. t. 13.

Type: China, s.n. (BR photo!).

Scandent shrubs, woody, laticiferous. Branches and branchlets densely stellate-pubescent. Leaves opposite, simple, pinnately nerved, hairy. Inflorescence axillary, paniculate, multiflowered, densely stellate hairy. Flowers bisexual, small. Calyx (2-) 4 (or 5)-partite, segments unequal in length. Petals 3, rarely 4, sepal-like, reflexed. Stamens numerous, on a disk; filaments filiform, free; anthers dehiscing transversely. Gynoecium 3-carpellary, syncarpous. Ovary superior, 3-loculed, sessile, densely tomentose; ovules 2 per locule; style 1, subulate; stigma minutely 3-lobed. Fruit a turbinate septicidal capsule with 3 spreading wings ultimately separating into 3 cocci. Seeds ovate. 
Plagiopteron suaveolens Griff., Calcutta J. Nat. Hist. 4: 244 (1843); Ya Tang \& Sue Zmarzty, Fl. China 11: 439 (2007). P. chinensis X.X. Chen, Acta Bot. Yunnan 2(3): 331 (1980); P. fragrans Griff. Calcutta J. Nat. Hist. 4: 244 (1843) t.13.

Type: China, s.n. (BR photo!).

(Fig. 2).

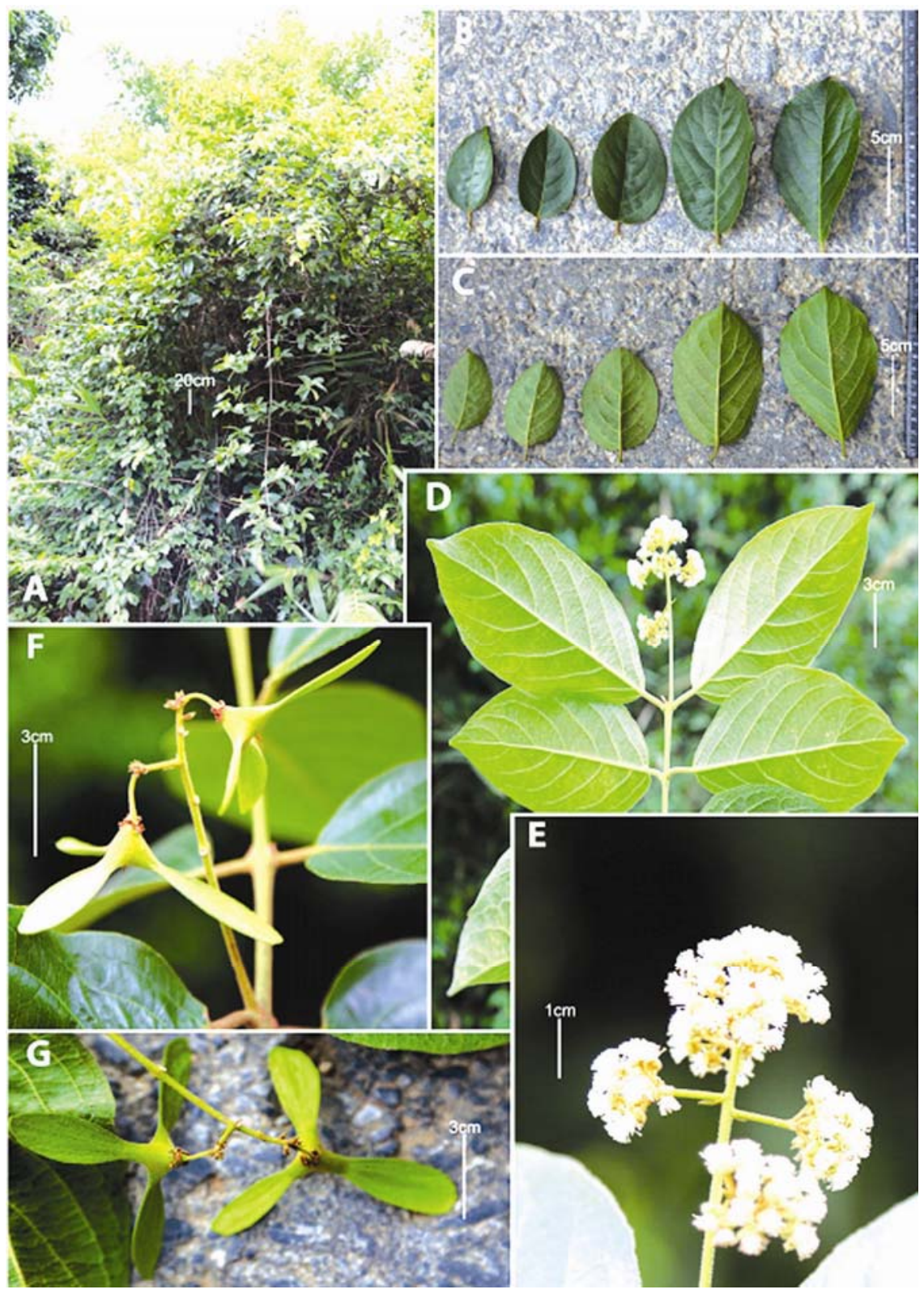

Fig. 2. Plagiopteron suaveolens A. Habit; B. \& C. Adaxial and abaxial surface of leaf; D. A flowering twig; E. Flowers; F. Infructescence; G. Fruits. 
A large scandent shrub; young parts rusty stellate-pubescent. Petiole c. $1.0-1.5 \mathrm{~cm}$ long, densely tomentose; leaf blade elliptic, ovate-elliptic, ovate-oblong or nearly round, 3.0 - $13.5 \times 2.5$ $-7.5 \mathrm{~cm}$, papery, abaxially densely brown stellate tomentose, adaxially finally pubescent on veins only, midvein strongly prominent abaxially, raised adaxially, lateral veins 5 or 7 pairs, base rounded or slightly cordate, less often acute to obtusely cuneate, or apparently finely crenate in dried material; margin entire; apex acute to acuminate. Inflorescence paniculate, axillary, toward twig apex, usually shorter than leaf blade; peduncle densely brown stellate tomentose, lower unbranched part of peduncle 4.5 - $5.0 \mathrm{~cm}$ long. Pedicel flower c. 5.0 - $6.5 \mathrm{~mm}$ long, tomentose; bracteoles lanceolate, 2.0 - $3.0 \mathrm{~mm}$ long. Sepals 4 , spreading, hairy, unequal in size, lanceolate, 1.0 - $1.5 \mathrm{~mm}$ long, tomentose. Petals 3 or 4 , nearly round or, narrowly ovate, 2.5 - $3.5 \mathrm{~mm}$ long, outside tomentose, yellow, inside with sparser weak hairs. Stamens many, on a disk, slightly united at base, much longer than petals; filaments filiform, slightly dilated above, $2.0-3.0 \mathrm{~mm}$ long, glabrous; anthers globose or pyriform, minute, glabrous, dehiscent by apical pores. Ovary superior, densely brown pubescent, 3-loculed with 2 basal erect ovules in each locule; style subulate, simple, c. $2.0 \mathrm{~mm}$ long, slender, tapering to apex, nearly as long as filaments, tomentose at base; stigma minutely 3-lobed. Capsules turbinate, woody, expanded at apex into 3 spreading wings and ultimately separating into 3 cocci; wings spathulate, $2.0-4.0 \mathrm{~cm}$ long, unequal with subparallel veins, sparsely stellate hairy. Seeds ovate c. $0.3-0.5 \mathrm{~mm}$ long.

Flowering: May to June; fruiting: July.

Specimens examined: Vietnam, Bac Giang Province, Son Dong district, An Lac Village, 18 July 2015, c. N2122'11.1" E10656'02.8", 166 masl, T.T. Bach, T.D. Binh, V.T. Chinh, D.V. Hai, B.H. Quang, D.H. Son, VK-6488 (HN, KRIBB).

Ecology: Plagiopteron suaveolens was found growing in the shade along the streams and at the forest borders of limestone hills at about $166 \mathrm{~m}$ asl. However, it has also been reported to occur in the open evergreen forest, secondary forest (evergreen forest type), open deciduous forest, or sometimes at the edge of cultivation from Thailand at the altitudinal range of $80-430 \mathrm{~m}$ asl (Phonsena, 2004).

Distribution: Vietnam (Bac Giang Province, Son Dong District, An Lac village). Bangladesh (Silhet), China (Guangxi), Myanmar (Tenasserim) and Thailand (Lampang, Kalasin, Nakhon Ratchasima, Sa Kaeo).

\section{Leaf anatomical features}

Leaf anatomical characteristics of Plagiopteron suaveolens are described under two headings.

(Fig. 3).

\section{Central vein}

The epidermis cells cover the entire leaf surface and are continuous with the surface of stem to which the leaf is attached. The upper epidermal cells (B) are single layered with some unicellular-hairs (A); the lower epidermis consists of ordinary cells and guard cells (I). The guard cells occur in pair, separated by an opening or pore (stoma). The epidermal cells are continued by plenty of collenchyma-cell layers (C).

The transverse section shows the vascular systems in central veins. The vascular bundles extend throughout the leaf. The conducting elements are xylem (E) and phloem (D).

Some sclerenchyma cells (F) were observed in the Central part. Leaf blade

The upper and lower epidermis cells are continued with those which occur in Central veins. 
Mesophyll of leaf consists of 3 parts: the sub-epidermis $(G)$; the palisade parenchyma $(H)$ and the spongy parenchyma. The upper epidermis cells are followed by two layers of sub-epidermis and the palisade parenchyma layer with narrow cells $(\mathrm{H})$. The spongy parenchyma $(\mathrm{J})$ extends from the palisade parenchyma $(\mathrm{K})$ to the lower epidermis. Cells of the spongy parenchyma are irregular in shape and loosely arranged.

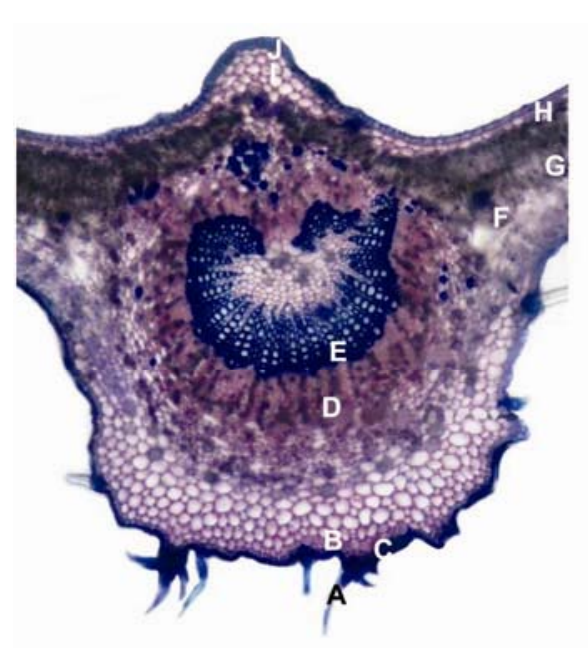

Transverse Section (T.S.)

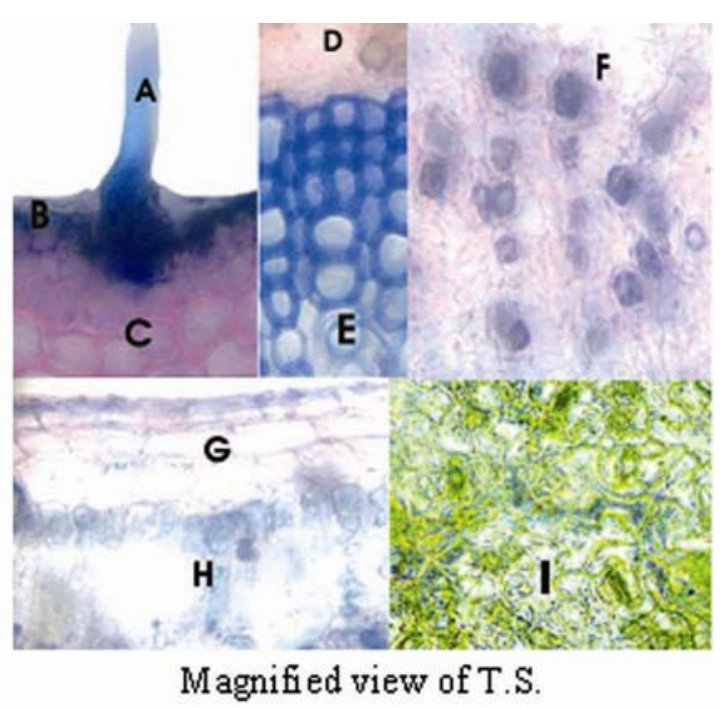

Magnified view of T.S.

Fig. 3. Detailed leaf anatomical characteristics of Plagiopteron suaveolens as seen in transverse section. A. Unicellular hair; B. Upper Epidermis; C. Collenchyma cells; D. Phloem; E. Xylem; F. Sclerenchyma cells; G. Sub-epidermis; H. Palisade parenchyma; I. Guard cells; J. Spongy parenchyma; K. Palisade parenchyma; L. Sub-epidermis; M. Upper collenchyma; N. Upper epidermis.

\section{Taxonomic Notes}

The genus Plagiopteron was earlier placed under the monotypic family Plagiopteraceae (Bass et al., 1979) however, its woody climbing habit, the presence of large opposite leaves, small flowers in many-flowered terminal cymes, and fruit with Acer-like wings pointed out its affinity with Celastraceae. Further similarities were found in the elastic material of the leaf midrib vascular cylinder. Nonetheless, the pollen characters did not support its placement in Celastraceae (Tang, 1994). Recent systematic studies using molecular data placed Plagiopteron in the Celastraceae, close to the Hippocrateoid genera. The genus is supposedly an early derived member of the subfamily Hippocrateoideae (composed of tribes Campylostemoneae and Hippocrateeae), within Hippocrateaceae. This relationship has been supported by the molecular studies using 26S $n r D N A, r b c L$, atpB and phyB loci (Simmons et al., 2001b; Savolainen et al., 2000, 2000b; Soltis et al., 2000). This relationship is also consistent with recognition of the embryological similarities between Plagiopteron and Celastraceae (Tang, 1994) and simultaneous analysis of $r b c L$ and morphological characters (Nandi et al., 1998). Synapomorphies of Plagiopteron with Hippocrateaceae are extrose, transversely dehiscent stamens that are not versatile. Plagiopteron, however differs from other members of Celastraceae by its many bicyclically arranged stamens. A synapomorphy of Plagiopteron with Hippocrateoideae is the distinctive capsular fruits that are deeply lobed between the locules (Simmons et al., 2001a). The present report will help to prioritize conservation of this species in Vietnam, Bangladesh, China, Thailand and Myanmar. 


\section{Acknowledgments}

We are thankful to the Institute of Ecology and Biological Resources (IEBR), Vietnam Academy of Science and Technology Hanoi (VAST), Chungnam National University (CNU), International Biological Material Research Center (IBMRC), Korea Research Institute of Bioscience and Biotechnology (KRIBB), Korea and The National Foundation for Science and Technology Development (NAFOSTED-106-NN.99-2015.26) for permitting us to carry out this study. RKC (2nd author) acknowledges to the MoU between Agharkar Research Institute, India and IBMRC, KRIBB which facilitated this research. Thanks are also due to the anonymous reviewers for their constructive comments which helped the manuscript to improve further.

\section{References}

Ban, N.T. 2003. Celastraceae, In: Checklist of Plant Species of Vietnam. Vol. 2. Agricultural Publishing House, Vietnam, pp. 1120-1134.

Baas, P., Geesink, R., van Heel, W.A. and Muller, J. 1979. The affinities of Plagiopteron suaveolens Griff. (Plagiopteraceae). Grana. 18: 69-89.

Cutler, D.F., Botha T. and Stevenson D.W. 2007. Plant Anatomy: an applied approach. Blackwell Publishing, Malden, pp. 1-302.

Den Hartog, R.M., Tholen, V. and Bass, P. 1978. Epidermal characters of the Celastraceae sensu lato. Acta Bot. Neerl. 27: 355-388.

Jain, S.K. and Rao, R.R. 1977. A Handbook of Field and Herbarium Methods. Today and Tomorrow's Printers and Publishers, New Delhi, pp. 1-157.

Johansen, D.A. 1940. Plant microtechnique. New York, Mc. Graw Hill Book.

Mennega, A.M.W. 1997. Wood Anatomy of the Hippocrateoideae (Celastraceae). IAWA-Journal. 18(4): 331-368.

Nandi, O.I., Chase, M.W. and Endress, P.K. 1998. A combined cladistic analysis of angiosperms using rbcL and non-molecular data sets. Ann. Mo. Bot. Gard. 85: 137-212.

Phonsena, P. 2004. Plagiopteron suaveolens (Plagiopteraceae): an emended description. Thai Forest Bulletin (Botany), 32: 123-131.

Robinson, H. 1969. A monograph on foliar anatomy of the genera Connelia, Cottendorfia, and Navia (Bromeliaceae). Smithsonian Contrib. Bot. 2: 1-41.

Savolainen, V., Fay, M.F., Albach, D.C., Backlund, A., van der Bank, M., Cameron, K.M., Johnson, S.A., Lledo, M.D., Pintaud, J.-C., Powell, M., Sheahan, M.C., Soltis, D.E., Soltis, P.S., Weston, P., Whitten, M., Wurdack, K.J., and Chase, M.W. 2000a. Phylogeny of the eudicots: A nearly complete familial analysis based on rbcL gene sequences. Kew Bull. 55: 257-309.

Savolainen, V., Chase, M.W., Hoot, S.B., Morton, C.M., Soltis, D.E., Bayer, C., Fay, M.F., De Brujin, A., Sullivan, S., and Qiu, Y.-L. 2000b. Phylogenetics of flowering plants based upon a combined analysis of plastid atpB and rbcL gene sequences. Syst. Biol. 49: 306-362.

Simmons, M.P. 2001. Celastraceae. In: Kubitzki K. (Ed.), The Families and Genera of Vascular Plants. Vol. 6. Springer-Verlag, Berlin, pp. 29-64.

Simmons, M.P., Clevinger, C.C., Savolainen, V., Archer, R.H., Mathews, S. and Doyle, J.J. 2001 b. Phylogeny of the Celastraceae inferred from phytochrome B and morphology. Am. J. Bot. 88: 313-325.

Smith, L.B. and Robinson, H.E. 1971. Hippocrateaceas. In: Reitz, R. (ed.), Flora Ilustrada Catarinense. Itajai, Herbario Barbosa Rodrigues, pp. 1-33.

Soltis, D.E., Soltis, P.S., Chase, M.W., Mort, M.E., Albach, D.C., Zanis, M., Savolainen, V., Hahn, W.H., Hoot, S.B., Fay, M.F., Axtell, M., Swensen, S.M., Nixon, K.C. and Farris, J.S. 2000. Angiosperm phylogeny inferred from a combined data set of $18 \mathrm{~S}$ rDNA, rbcL, and atpB sequences. Bot. J. Linn. Soc. 133: 381-461.

Tang, Y. (1994). Embryology of Plagiopteron suaveolens Griffith (Plagiopteraceae) and its systematic implications. Bot. J. Linn. Soc. 116: 145-157. 